Article

\title{
Risk Assessment of the Schmutzdecke of Biosand Filters: Identification of an Opportunistic Pathogen in Schmutzdecke Developed by an Unsafe Water Source
}

\author{
Hyun Gyu Hwang ${ }^{1, \dagger}$, Min Seo Kim ${ }^{1, \dagger}$, Soo Min Shin ${ }^{1}$ and Cher Won Hwang ${ }^{2, *}$
}

1 School of Life Science, Handong Global University, Gyeongsangbuk-do, Pohang 791-708, Korea; E-Mails: gusrbcpt90@naver.com (H.G.H.); minseolike@naver.com (M.S.K.); soomin.shin@hotmail.com (S.M.S.)

2 Global Leadership School, Handong Global University, Gyeongsangbuk-do, Pohang 791-708, Korea

$\dagger$ These authors contributed equally to this work.

* Author to whom correspondence should be addressed; E-Mail: chowon@handong.edu; Tel.: +82-54-260-1304.

Received: 2 January 2014; in revised form: 31 January 2014 / Accepted: 8 February 2014 / Published: 14 February 2014

Abstract: The biosand filter (BSF) is widely applied in developing counties as an appropriate technology-based product for supplying "safe" water. Biosand filters exhibit relatively high purifying efficiency because of the schmutzdecke (biofilm) embedded in them. However, schmutzdecke should be cleaned or discarded on a regular basis to maintain the purifying efficiency of the BSF. Due to its role in BSFs, the purifying function of schmutzdecke, rather than its potential risk when not properly discarded, has so far been the primary focus of research. This study aims to provide a risk assessment of schmutzdecke in an attempt to draw attention to a wholly new angle of schmutzdecke usage. We conducted 16S rRNA gene sequencing and phylogenetic analysis to identify opportunistic pathogens in schmutzdecke developed using water from the Hyung-San River. The results reveal that the schmutzdecke derived from this water source contains diverse and relatively high portions of opportunistic pathogen strains; $55 \%$ of all isolates collected from schmutzdecke were identified as opportunistic pathogens. Moreover, the diversity of microorganisms is increased in the schmutzdecke compared to its water source in terms of diversity of genus, phylum and opportunistic pathogen strain. As a whole, our study 
indicates a potential risk associated with schmutzdecke and the necessity of a solid guideline for the after-treatment of discarded schmutzdecke.

Keywords: opportunistic pathogen; nearest phylogenetic neighbor; biosand filter; schmutzdecke; 16S rRNA gene sequencing

\section{Introduction}

Many developing countries are facing water problems, both in terms of lacking sufficient supplies of water and producing "clean" water. It is reported that more than 1.1 billion people are suffering from a lack of safe water [1]. To solve this problem, developing countries need to build a solid base for a water treatment system. However, such systems are very expensive, and thus, an alternative solution using "appropriate technology" is attracting attention [2].

Appropriate technology, also known as intermediate technology, is a term describing a technology that is designed to provide minimal technical challenges to people living in circumstances where high technology is difficult to apply. Differing from high technology, appropriate technology uses simple and low-cost materials that are easily obtainable in the locale and does not require specialized techniques [3]. Due to these characteristics, appropriate technology is increasingly frequently applied in developing countries.

The biosand filter (BSF) is one of the most widely applied appropriate technology-based products. The 2012 Annual Report of the Centre for Affordable Water and Sanitation Technology (CAWST) presents statistical data indicating that 5,981,000 people are impacted by the water sanitation project encompassing biosand filters (BSF) [4]. Furthermore, according to the CAWST database, over 200,000 BSFs have been installed globally so far, 12,346 institutions are participating in supplying BSFs, and 37 countries are taking advantage of BSF systems [5].

Even though the biosand filter is composed of easily obtainable and simple materials, such as sand, it exhibits relatively high biological purification efficiency, removing 93-99\% of fecal coliform bacteria [6] and $99.9 \%$ of protozoa [7]. Underlying the relatively high biological purifying effect of the BSF is its schmutzdecke (biofilm). BSF provides an appropriate condition for the growth of microorganisms, encouraging them to form a biofilm called schmutzdecke (Figure 1). The microorganisms composing the schmutzdecke, in turn, prey on other harmful microorganisms contained in the contaminated input water, converting them to harmless inorganic matter [8]. Moreover, various microorganisms from the input water source attach to the sand surface and accumulate to become part of schmutzdecke [9]. The participation of water source-originated microorganisms in schmutzdecke further increases the biological purification efficacy.

Because schmutzdecke clogs and prevents water flow through the filter as it develops, it should be cleaned or discarded on a regular basis to maintain the BSF [10]. As a general rule, people using BSFs dump or pour waste of the schmutzdecke to nearby water sources, such as ditches, lakes, or rivers, for their convenience and without much awareness. This practice has continued because there have been no solid guidelines for the after-treatment of schmutzdecke deposits. No one has cast any doubts on the traditional method of discarding schmutzdecke and whether it possesses potential risk. Due to its role 
in the BSF, so far, the main focus of schmutzdecke research has been its purifying function rather than the potential risks it poses. Because it examines the potential negative side of schmutzdecke, which has thus far been neglected, this paper is expected to bring attention to an entirely new aspect of schmutzdecke. This paper aims to perform a risk assessment of schmutzdecke by evaluating the opportunistic pathogens and suggesting the necessity of guidelines for the after-treatment of schmutzdecke.

Figure 1. Biosand filter (source: [11]).

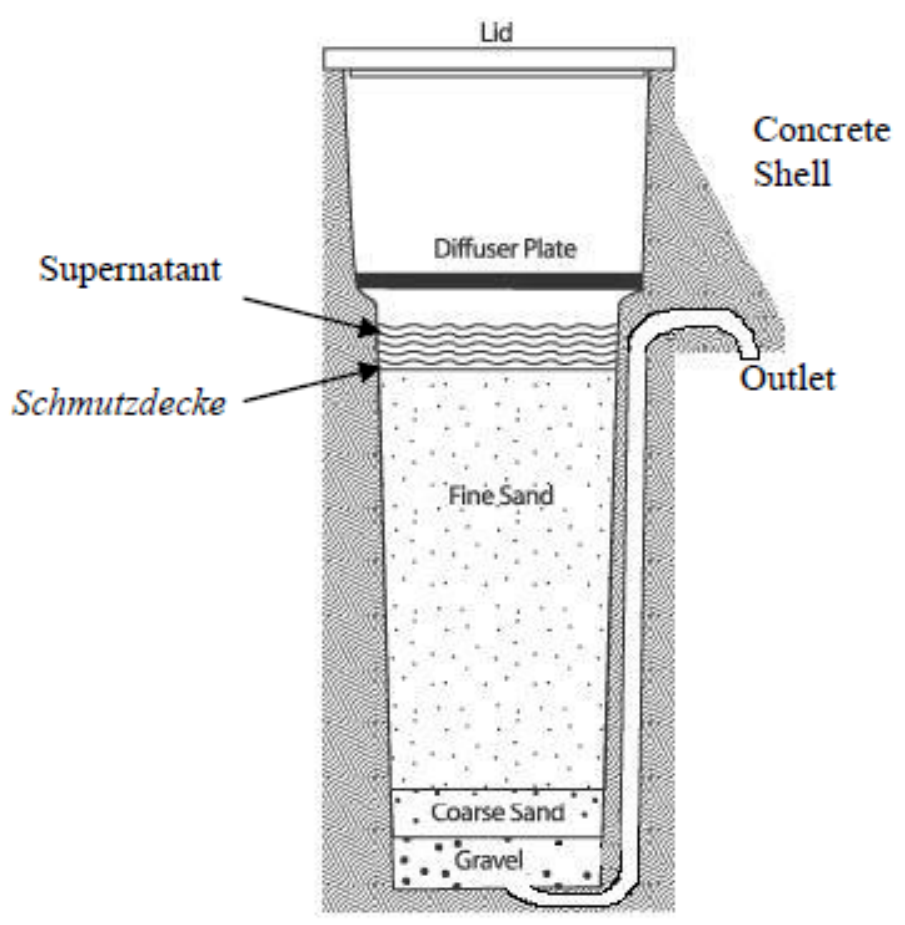

\section{Experimental Section}

\subsection{Source of Samples}

\subsubsection{Sample Collection from Hyung-San River}

Samples were collected from two different sources: the Hyung-San River (latitude: 36.006826/longitude: 129.361632) in Pohang, South Korea, and the schmutzdecke of biosand filters. Water was collected at $30 \mathrm{~cm}$ below the surface of the Hyung-San River on 23 September 2013, and a basic water condition test was conducted within 2 hours. The results were as follows: $\mathrm{pH}$ 6.77, salinity $3.4 \mathrm{ppt}$, conductivity $6.28 \mathrm{~ms} / \mathrm{cm}$, resistance $0.002 \mathrm{M} \Omega-\mathrm{cm}$, SS $3075 \mathrm{mg} / \mathrm{L}$, COD $3.4 \mathrm{mg} / \mathrm{L}$, DO $8.23 \mathrm{mg} / \mathrm{L}$. A $100 \mu \mathrm{L}$ aliquot of the water sample was cultured in Plate Count Agar (BD DIFCO, 247940) medium in triplicate over a dilution range of $10^{-1}-10^{-7}$. The 21 plates prepared (three sets of seven differently diluted plates) were incubated at $25^{\circ} \mathrm{C}$ room temperature for 2 days, and 17 strains were isolated according to distinct colony morphologies. 


\subsubsection{Sample Collection from the Schmutzdecke (Biofilm) of Biosand Filters}

A minimized model of a biosand filter was constructed according to the manual offered by CAWST [10]. A container composed of polyethylene phthalate was used, and the specific parameters of the constructed minimized biosand filter were as follows: container height $30.0 \mathrm{~cm}$, sand height $20.0 \mathrm{~cm}$, container diameter $9.5 \mathrm{~cm}$, diffuser hole diameter $0.3 \mathrm{~cm}$, and sand grain size $0.7-1.0 \mathrm{~mm}$. Twice a day, $300 \mathrm{~mL}$ of water was supplied to maintain a standing water zone of $5 \mathrm{~cm}$ above the sand surface with a pause period of 12 hours. The schmutzdecke (biofilm) embedded in BSF was developed for 4 weeks using the Hyung-San River as the water source. Schmutzdecke was mixed with PBS buffer and vortexed. Then, $100 \mu \mathrm{L}$ of extracted sample was cultured in Plate Count Agar (BD DIFCO, 247940) medium in triplicate over a dilution range of $10^{-1}-10^{-7}$. The 21 prepared plates were incubated at $25{ }^{\circ} \mathrm{C}$ room temperature for 2 days, and 20 strains were isolated according to distinct colony morphologies.

\subsection{DNA Isolation}

Each isolated sample was added to a $1.5 \mathrm{~mL}$ microtube, vortexed in $\mathrm{DW}$ and centrifuged for $1 \mathrm{~min}$ at $13,000 \mathrm{~g}$. After removing the supernatant, $300 \mu \mathrm{L}$ of cell resuspension solution (Solutions for Genetic Technology, Seoul, Republic of Korea) and $2 \mu \mathrm{L}$ of lysozyme $(100 \mathrm{mg} / \mathrm{mL})$ were added, and the samples were incubated at $37^{\circ} \mathrm{C}$ for $60 \mathrm{~min}$. Again, the samples were centrifuged for $1 \mathrm{~min}$ at 13,000 g. Then, $300 \mu \mathrm{L}$ of Cell Lysis Solution (Solutions for Genetic Technology) and 1.5 $\mu \mathrm{L}$ of RNase A $\left(4 \mathrm{mg} / \mathrm{mL}\right.$ ) were added and mixed with the samples. After incubation at $37{ }^{\circ} \mathrm{C}$ for $30 \mathrm{~min}$, the samples were cooled to room temperature, and $100 \mu \mathrm{L}$ Protein Precipitation Solution (Solutions for Genetic Technology) was added. The samples were centrifuged for $5 \mathrm{~min}$ at 13,000 g, and the supernatants were transferred to new $1.5 \mathrm{~mL}$ microtubes containing $300 \mu \mathrm{L}$ of $100 \%$ isopropanol. Then, the samples were washed twice with $500 \mu \mathrm{L}$ of WB $(80 \%$ Ethanol) with inverting. The supernatant liquid was removed with a micropipette, and the remaining pellet was dried at room temperature for $15 \mathrm{~min}$. Subsequently, $100 \mu \mathrm{L}$ of DNA Hydration solution (Solutions for Genetic Technology) was added, and the DNA was dissolved thoroughly through vortexing. The samples were incubated at $65^{\circ} \mathrm{C}$ for $60 \mathrm{~min}$, and the concentration of prepared DNA was confirmed through overnight electrophoresis.

\subsection{PCR Amplification and Purification}

Extracted DNA was amplified through PCR with a Veriti R TM 96-well Thermal Cycler (Applied Biosystems, Marsiling, Singapore), using the universal primer pair of 27F (5'-AGAGTTTGATCCTGGCTCAG-3') and 1492R (5'-GGTTACCTTGTTACGACTT-3'). The DNA sample solution $(3.0 \mu \mathrm{L})$ was mixed with $2.5 \mu \mathrm{L}$ of $10 \mathrm{x}$ EF-Taq Buffer, $0.5 \mu \mathrm{L}$ of $10 \mathrm{mM} \mathrm{dNTP}(\mathrm{T}), 1.0 \mu \mathrm{L}$ of primer (F10), $1.0 \mu \mathrm{L}$ of primer (R10p), $0.3 \mu \mathrm{L}$ of EF-Taq $(2.5 \mathrm{U})$, and $16.7 \mu \mathrm{L}$ of DW. The PCR protocol included a denaturation step at $95^{\circ} \mathrm{C}$ for $15 \mathrm{~min}$ followed by 30 cycles of 3 constitutive steps: thermal cycling for $20 \mathrm{sec}$ at $95{ }^{\circ} \mathrm{C}, 40 \mathrm{sec}$ at $50^{\circ} \mathrm{C}$, and $1 \mathrm{~min}$ and $30 \mathrm{sec}$ at $72{ }^{\circ} \mathrm{C}$. The final termination step was performed at $72{ }^{\circ} \mathrm{C}$ for $5 \mathrm{~min}$. The amplified DNA was purified with an Ultra PCR Purification Kit (SolGent, Seoul, Republic of Korea) according to the manufacturer's instructions. 


\subsection{S rRNA Gene Sequencing}

The purified DNA $(1.0 \mu \mathrm{L})$ from each strain was mixed with $4.0 \mu \mathrm{L}$ of Terminator Ready Reaction Mix (Solutions for Genetic Technology), $1 \mu \mathrm{L}$ of primer $(5 \mathrm{pmol})$, and $4 \mu \mathrm{L}$ of sterilized water, for a total reaction volume of $10 \mu \mathrm{L}$. Subsequently, the reaction tubes were subjected to the process of cycle sequencing, with 30 repeating thermal cycles at $96{ }^{\circ} \mathrm{C}$ for $10 \mathrm{sec}, 50 \quad{ }^{\circ} \mathrm{C}$ for 5 seconds, and $60{ }^{\circ} \mathrm{C}$ for $4 \mathrm{~min}$. Loading buffer (15 $\mu \mathrm{L}$ of Hi-Di Formamide) was added to $10 \mu \mathrm{L}$ of each prepared reaction tube and then mixed and centrifuged during the final step. Each sample was heated for $4 \mathrm{~min}$ at $95{ }^{\circ} \mathrm{C}$, immediately transferred to ice, and loaded on the ABI 3730XL DNA Analyzer (Applied Biosystems, Foster City, CA, USA) for sequencing.

\subsection{Phylogenetic Analysis}

Gene sequences for the 16S rRNA of the isolates were analyzed and identified for the nearest phylogenetic neighbor using the Basic Local Alignment Search (BLAST) tool from NCBI (National Center for Biotechnology Information, Bethesda, MD, USA) [12] and were aligned by using ClustalW in the MEGA software package (version 6.05). Neighbor-joining phylogenetic trees were constructed by the Maximum-Likelihood method in MEGA 6.05. Confidence values for nodes were measured using bootstrap resampling (1,000 replications) [13].

\section{Results}

\subsection{Comparing the Diversity and Proportions of Microorganisms from Two Different Sources}

Seventeen strains of bacteria were isolated from the Hyung-San River: Novosphingobium, Catellibacterium, Aeromonas, Leclercia, Raoultella from the phylum Proteobacteria and Microbacterium from the phylum Actinobacteria. Of these 17 strains, five isolates were identified as opportunistic pathogens (29\%) according to the 16S rRNA-based phylogenic analysis. Twenty strains were isolated from the schmutzdecke of the BSF that was developed by supplying Hyung-San River for nutrients and organic matter: Brevibacillus from the phylum Firmicutes; Cloacibacterium from the phylum Bacteroidetes; Streptomyces, Microbacterium, and Arthrobacter from the phylum Actinobacteria; and Novosphingobium, Sphingomonas, Bradyrhizobium, Klebsiella, Enterobacter, Aeromonas, and Pantoea from the phylum Proteobacteria. Of the 20 strains, nine isolates were identified as opportunistic pathogen (55\%) according to $16 \mathrm{~S}$ rRNA-based phylogenic analysis (Table 1). Besides, reported fecal pollution indicators such as Klebsiella oxytoca, Pantoea agglomerans, and Enterobacter aerogenes were also isolated from the schmutzdecke [14]. 
Table 1. Number of isolates, observed genus, observed phylum, and \%strain of opportunistic pathogen in two different sources: Hyung-San River and Schmutzdecke developed by Hyung-San River.

\begin{tabular}{|c|c|c|c|c|c|}
\hline Source & Labeling & $\begin{array}{c}\text { Number of } \\
\text { Isolates } \\
\end{array}$ & Observed genus & $\begin{array}{c}\text { Observed } \\
\text { Phylum }\end{array}$ & $\begin{array}{c}\text { \% Strain of Opportunistic } \\
\text { Pathogens } \\
\end{array}$ \\
\hline $\begin{array}{l}\text { Hyung-San } \\
\text { River }\end{array}$ & $\mathrm{H}$ & 17 & $\begin{array}{c}\text { Novosphingobium, } \\
\text { Catellibacterium, } \\
\text { Aeromonas, } \\
\text { Leclercia, } \\
\text { Raoultella, } \\
\text { Microbacterium, }\end{array}$ & $\begin{array}{l}\text { Proteobacteria, } \\
\text { Actinobacteria }\end{array}$ & $29 \%$ \\
\hline $\begin{array}{c}\text { Schmutzdecke } \\
\text { (biofilm) of } \\
\text { BSF }\end{array}$ & $\mathrm{HB}$ & 20 & $\begin{array}{c}\text { Novosphingobium, } \\
\text { Sphingomonas, } \\
\text { Bradyrhizobium, } \\
\text { Klebsiella, } \\
\text { Enterobacter, } \\
\text { Aeromonas, } \\
\text { Pantoea, } \\
\text { Cloacibacterium, } \\
\text { Streptomyces, } \\
\text { Arthrobacter } \\
\text { Microbacterium, } \\
\text { Brevibacillus. }\end{array}$ & $\begin{array}{c}\text { Proteobacteria } \\
\text { Actinobacteria, } \\
\text { Fermicutes, } \\
\text { Bacteroidetes }\end{array}$ & $55 \%$ \\
\hline
\end{tabular}

\subsection{Phylogenic Analysis of Isolated Strains from Samples}

The nearest phylogenic neighbor of all 37 isolates from the Hyung-San River and schmutzdecke was determined by using the BLAST tool from NCBI based on the 16S rRNA gene sequence. The result of the BLAST analysis revealed that of all the strains, four strains belonged to the genus Novosphingobium resinovorum, one strain belonged to the genus Catellibacterium, two strains belonged to the genus Sphingomonas, two strains belonged to the genus Bradyrhizobium, four strains belonged to the genus Bradyrhizobium, one strain belonged to the genus Leclercia, one strain belonged to the genus Raoultella, one strain belonged to the genus Klebsiella, two strains belonged to the genus Enterobacter, two strains belonged to the genus Pantoea, three strains belonged to the genus Cloacibacterium, 10 strains belonged to the genus Microbacterium, two strains belonged to the genus Streptomyces, and one strain belonged to the genus Brevibacillus (Table 2 and Figure 2).

The phylogenetic tree of the Hyung-San River species (Figure 2) shows the affiliation of 17 strains consisting of 11 different taxa. All the strains of the isolates from the Hyung-San River were divided into four Gram-positive groups and seven Gram-negative groups. All four Gram-positive groups, which include $\mathrm{H} 3, \mathrm{H} 6, \mathrm{H} 7, \mathrm{H} 9, \mathrm{H} 12, \mathrm{H} 13, \mathrm{H} 14, \mathrm{H} 15$, and $\mathrm{H} 17$, belonged to the phylum Actinobacteria. Of the seven Gram-negative groups, four groups, which include H2, H4, H5, H10, and H11, belonged to the phylum Gammaproteobacteria, and three groups, which include H1, H8, and H16, belonged to the phylum Alphaproteobacteria (Figure 2). 
Table 2. Identification of 37 isolated strains from Hyung-San River and Schmutzdecke for their nearest phylogenic neighbors according to $16 \mathrm{~S}$ rRNA gene sequence similarity\%.

\begin{tabular}{|c|c|c|c|}
\hline SI No. & Strain No. & Nearest Phylogenic Neighbor & $\begin{array}{c}\text { 16S rRNA Gene } \\
\text { Sequence Similarity \% }\end{array}$ \\
\hline & & Gram-negative bacterial strains & \\
\hline & & Proteobacteria & \\
\hline & & Alphaproteobacteria & \\
\hline 1 & $\mathrm{H} 1$ & Novosphingobium resinovorum strain SQ85 & 98.1 \\
\hline 2 & $\mathrm{H} 8$ & Catellibacterium aquatile strain A1-9 & 98.0 \\
\hline 3 & H16 & Novosphingobium subterraneum strain T4AR15 & 98.2 \\
\hline 4 & HB12 & Novosphingobium sp. HU1-AH51 & 98.8 \\
\hline 5 & HB13 & Sphingomonas sp. M16 & 99.7 \\
\hline 6 & HB15 & Sphingomonas sp. M16 & 99.6 \\
\hline 7 & HB17 & Novosphingobium aromaticivorans DSM_12444 & 97.7 \\
\hline 8 & HB19 & Bradyrhizobium sp. CCBAU 7128301 & 99.0 \\
\hline \multirow[t]{2}{*}{9} & HB20 & Bradyrhizobium sp. CCBAU 7128301 & 98.6 \\
\hline & & Gammaproteobacteria & \\
\hline 10 & $\mathrm{H} 2$ & Aeromonas hydrophila strain AN-3 & 99.8 \\
\hline 11 & $\mathrm{H} 4$ & Leclercia adecarboxylata strain HPC21 & 99.6 \\
\hline 12 & H5 & Raoultella ornithinolytica strain B18 & 99.7 \\
\hline 13 & $\mathrm{H} 10$ & Aeromonas caviae strain T84 & 99.7 \\
\hline 14 & H11 & Aeromonas hydrophila strain AN-3 & 99.6 \\
\hline 15 & HB2 & Klebsiella oxytoca strain LF-1 & 99.5 \\
\hline 16 & HB4 & Enterobacter aerogenes strain DCH-2 & 99.5 \\
\hline 17 & HB5 & Aeromonas hydrophila strain AN-3 & 99.7 \\
\hline 18 & HB6 & Pantoea agglomerans strain 1BJN10 & 99.2 \\
\hline 19 & HB7 & Enterobacter cancerogenus strain KNUC5008 & 98.9 \\
\hline \multirow[t]{3}{*}{20} & HB14 & Pantoea agglomerans strain 1BJN10 & 99.7 \\
\hline & & Bacteroidetes & \\
\hline & & Flavobacteria & \\
\hline 21 & HB8 & Cloacibacterium normanense strain tu29 & 98.2 \\
\hline 22 & HB10 & Cloacibacterium rupense strain R2A-16 & 97.9 \\
\hline \multirow[t]{4}{*}{23} & HB18 & Cloacibacterium normanense strain tu29 & 98.0 \\
\hline & & Gram-positive bacterial strains & \\
\hline & & Actinobacteria & \\
\hline & & Actinobacteridae & \\
\hline 24 & $\mathrm{H} 3$ & Microbacterium flavescens strain 173 & 99.0 \\
\hline 25 & H6 & Microbacterium trichotecenolyticum strain 3370 & 99.8 \\
\hline 26 & $\mathrm{H} 7$ & Microbacterium laevaniformans strain 1 YJ19 & 99.6 \\
\hline 27 & H9 & Microbacterium trichotecenolyticum strain 3370 & 99.7 \\
\hline 28 & H12 & Microbacterium flavescens strain 173 & 99.3 \\
\hline 29 & H13 & Microbacterium trichotecenolyticum strain 3370 & 99.6 \\
\hline 30 & H14 & Microbacterium testaceum strain 343 & 99.7 \\
\hline 31 & H15 & Microbacterium testaceum strain 343 & 99.5 \\
\hline 32 & $\mathrm{H} 17$ & Microbacterium testaceum strain 343 & 99.6 \\
\hline
\end{tabular}


Table 2. Cont.

SI No. Strain No. Nearest Phylogenic Neighbor

16S rRNA Gene

\begin{tabular}{lclc}
\hline 33 & HB1 & Streptomyces sp. MJM3179 & 99.8 \\
34 & HB3 & Arthrobacter oryzae strain T42 & 99.2 \\
35 & HB9 & Microbacterium laevaniformans strain 1YJ19 & 99.5 \\
36 & HB11 & $\begin{array}{l}\text { Streptomyces sp. MJM3179 } \\
\text { Fermicutes }\end{array}$ & 99.9 \\
& & $\begin{array}{l}\text { Bacilli } \\
\text { Brevibacillus panacihumi strain C17 }\end{array}$ \\
\hline
\end{tabular}

Figure 2. Phylogenic tree based on neighbor-joining analysis of $16 \mathrm{~S}$ rRNA gene for Hyung-San River samples.




The phylogenic tree of the schmutzdecke (Figure 3) shows the affiliation of 20 strains consisting of 17 different taxa. All strains of the isolates from the schmutzdecke were divided into four Grampositive groups and 13 Gram-negative groups. Of the four Gram-positive groups, three groups, which include HB1, HB3, HB9, and HB11, belonged to the phylum Actinobacteria, and one group, HB16, belonged to the phylum Firmicutes. Of the 13 Gram-negative groups, four groups, which include HB2, HB4, HB5, HB6, HB7, and HB14, belonged to the phylum Gammaproteobacteria; six groups, which include HB12, HB13, HB15, HB17, HB19, and HB20, belonged to the phylum Alphaproteobacteria; and three groups, which include HB8, HB10, and HB18, belonged to the phylum Bacteroidetes.

Figure 3. Phylogenic tree based on neighbor-joining analysis of $16 \mathrm{~S}$ rRNA gene for schmutzdecke samples.

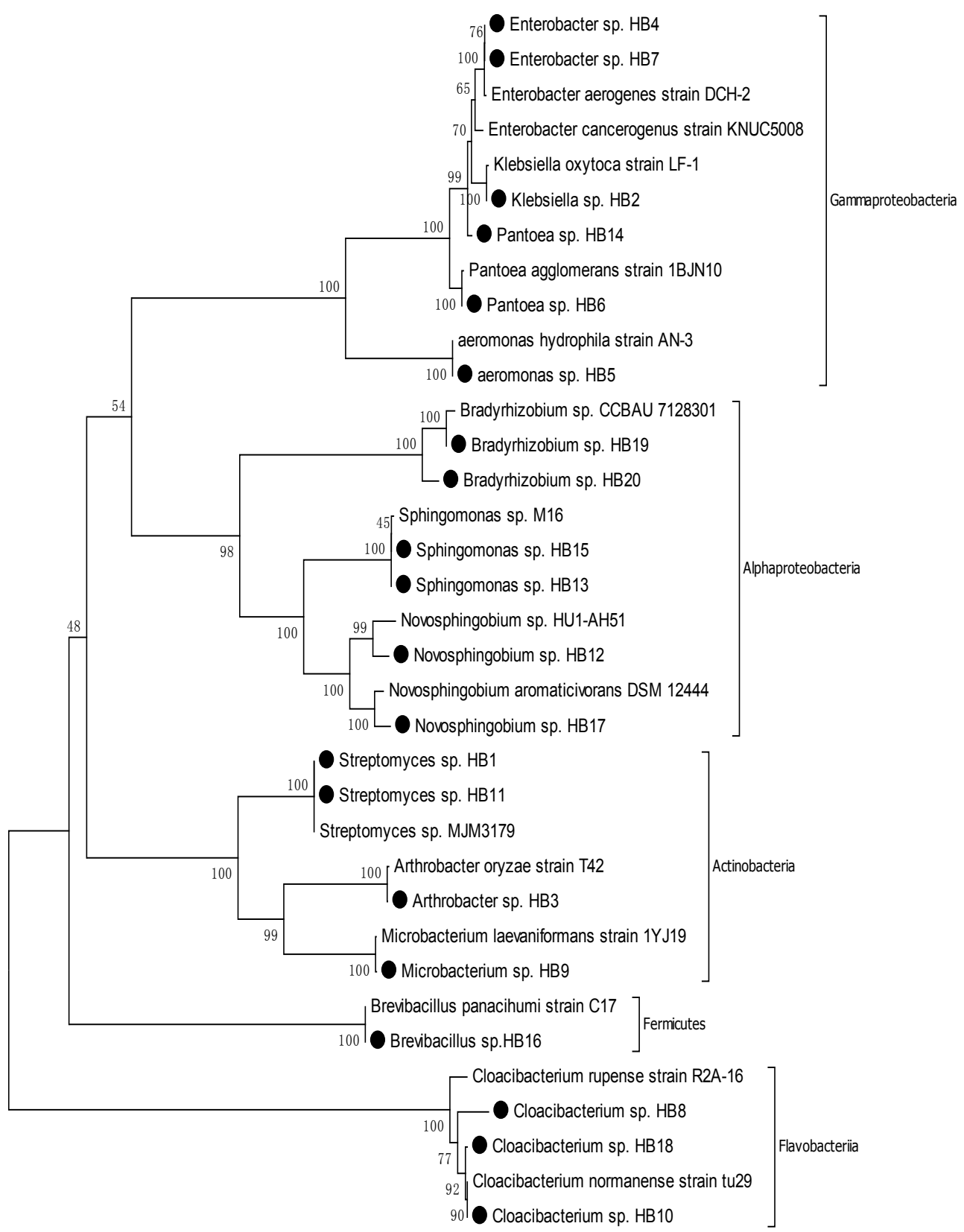




\subsection{Identification of Opportunistic Pathogens and Their Associated Diseases}

The nearest phylogenic neighbor of $\mathrm{H} 2$ and $\mathrm{H} 11$ was identified as Aeromonas hydrophila with 16S rRNA gene similarities of $99.8 \%$ and $99.6 \%$, respectively. Aeromonas hydrophila is known to be a Gram-negative/facultative anaerobic bacteria and is considered to be a pathogen that induces mild diarrhea, life-threatening necrotizing fasciitis, septicemia, meningitis, cholera-like illness and hemolytic-uremic syndrome [15]. The nearest phylogenetic neighbor of $\mathrm{H} 4$ was identified as Leclercia adecarboxylata with 16S rRNA gene similarity of $99.6 \%$. Leclercia adecarboxylata is Gram-negative/aerobic and is a pathogen that causes fever and leukocytosis [16]. The nearest phylogenic neighbor of H5 was identified as Raoultella ornithinolytica with 16S rRNA gene similarity of $99.7 \%$. Raoultella ornithinolytica is known to be Gram-negative/aerobic and facultative anaerobic, and it induces enteric fever-like syndrome and bacteremia [17]. The nearest phylogenic neighbor of $\mathrm{H} 10$ was identified as Aeromonas caviae with 16S rRNA gene similarity of $99.7 \%$. Aeromonas caviae is Gram-negative/facultative anaerobic and is known as a pathogen that causes gastrointestinal infectious diseases [18].

The nearest phylogenetic neighbor of HB1 and HB11 was identified as a Streptomyces sp. with 16S rRNA gene similarities of $99.8 \%$ and $99.9 \%$, respectively. Streptomyces sp. are Gram-positive/aerobic and are known to induce general hypersensitivity [19]. The nearest phylogenetic neighbor of HB2 was identified as Klebsiella oxytoca with 16S rRNA gene similarity of 99.5\%. Klebsiella oxytoca is Gram-negative/anaerobic and is considered to be a pathogen that causes septic arthritis [20]. The nearest phylogenic neighbor of HB4 was identified as Enterobacter aerogenes with 16S rRNA gene similarity of $99.5 \%$. Enterobacter aerogenes is Gram-negative/facultative aerobic and is known to be a pathogen that induces a wide variety of infections [21]. The nearest phylogenic neighbor of HB5 was identified as Aeromonas hydrophila with 16S rRNA gene similarity of 99.7\%. Aeromonas hydrophila is a known pathogen that causes symptoms previously mentioned. The nearest phylogenic neighbor of HB6 and HB14 was identified as Pantoea agglomerans with 16S rRNA gene similarity of 99.2\% and $99.7 \%$, respectively. Pantoea agglomerans is Gram-negative/aerobic and is a pathogen that causes soft tissue or bone/joint infections [22]. The nearest phylogenic neighbor of HB7 was identified as Enterobacter cancerogenus with $16 \mathrm{~S}$ rRNA gene similarity of $98.9 \%$. Enterobacter cancerogenus is Gram-negative/facultative anaerobic and causes wound and urinary tract infection, sepsis, and osteomyelitis [23]. The nearest phylogenic neighbor of HB17 was identified as Novosphingobium aromaticivorans with $16 \mathrm{~S}$ rRNA gene similarity of $97.7 \%$. Novosphingobium aromaticivorans is known to be Gram-negative/strictly aerobic and causes infection that induces autoimmune primary biliary cirrhosis [24]. Finally, the nearest phylogenic neighbor of HB13 and HB15 was identified as Sphingomonas $s p$. with $16 \mathrm{~S}$ rRNA gene similarities of $99.7 \%$ and $99.6 \%$, respectively. Sphingomonas $s p$. is known to be Gram-negative/aerobic and causes infectious disease [25] (Table 3). 
Table 3. Identification of opportunistic pathogens and their associated human diseases.

\begin{tabular}{|c|c|c|c|c|c|}
\hline $\begin{array}{r}\text { Sl } \\
\text { No. }\end{array}$ & $\begin{array}{c}\text { Nearest Phylogenic } \\
\text { Neighbor }\end{array}$ & Phylum & $\begin{array}{c}\text { General } \\
\text { Characteristics }\end{array}$ & $\begin{array}{c}\text { Associated Human } \\
\text { Disease } \\
\end{array}$ & Reference \\
\hline 1 & $\begin{array}{c}\text { Raoultella } \\
\text { ornithinolytica } \mathrm{B} 6\end{array}$ & Proteobacteria & $\begin{array}{c}\text { Gram-negative, } \\
\text { aerobic/facultative } \\
\text { anaerobic } \\
\end{array}$ & $\begin{array}{c}\text { Enteric fever-like } \\
\text { syndrome and bacteremia }\end{array}$ & $\begin{array}{l}\text { Victoria Pulian } \\
\text { Morais et al., } \\
2009[15] \\
\end{array}$ \\
\hline 2 & $\begin{array}{c}\text { Aeromonas caviae, } \\
\text { strain NCIMB } \\
13016\end{array}$ & Proteobacteria & $\begin{array}{c}\text { Gram-negative, } \\
\text { facultative } \\
\text { anaerobic }\end{array}$ & $\begin{array}{l}\text { Gastrointestinal } \\
\text { infectious disease }\end{array}$ & $\begin{array}{l}\text { Meiyanti et al., } \\
\quad 2010[16]\end{array}$ \\
\hline 3 & $\begin{array}{c}\text { Klebsiella oxytoca } \\
\text { strain LF-1 }\end{array}$ & Proteobacteria & $\begin{array}{c}\text { Gram-negative, } \\
\text { anaerobic }\end{array}$ & Septic arthritis & $\begin{array}{c}\text { Mendard A et al., } \\
2010[18]\end{array}$ \\
\hline 4 & $\begin{array}{c}\text { Enterobacter } \\
\text { aerogenes strain } \\
\text { DCH-2 }\end{array}$ & Proteobacteria & $\begin{array}{l}\text { Gram-negative, } \\
\text { facultative aerobic }\end{array}$ & All kinds of infections & $\begin{array}{c}\text { Irene G et al., } \\
2007[19]\end{array}$ \\
\hline 5 & $\begin{array}{c}\text { Pantoea } \\
\text { agglomerans strain } \\
\text { 1BJN10 } \\
\end{array}$ & Proteobacteria & $\begin{array}{l}\text { Gram-negative, } \\
\text { aerobic }\end{array}$ & $\begin{array}{l}\text { soft tissue or bone/joint } \\
\text { infections }\end{array}$ & $\begin{array}{c}\text { Andrea T et al., } \\
2007 \text { [20] }\end{array}$ \\
\hline 6 & $\begin{array}{c}\text { Enterobacter } \\
\text { cancerogenus strain } \\
\text { KNUC5008 }\end{array}$ & Proteobacteria & $\begin{array}{c}\text { Gram-negative, } \\
\text { facultative } \\
\text { anaerobic } \\
\end{array}$ & $\begin{array}{c}\text { Wound and urinary tract } \\
\text { infection, sepsis, and } \\
\text { osteomyelitis }\end{array}$ & $\begin{array}{l}\text { I. Stock et al., } \\
2002[21]\end{array}$ \\
\hline 7 & $\begin{array}{c}\text { Novosphingobium } \\
\text { aromaticivorans } \\
\text { DSM } 12444 \\
\end{array}$ & Proteobacteria & $\begin{array}{l}\text { Gram-negative, } \\
\text { strictly aerobic }\end{array}$ & $\begin{array}{c}\text { Autoimmune primary } \\
\text { biliary cirrhosis induced } \\
\text { by infection }\end{array}$ & $\begin{array}{l}\text { Mohammed JP } \\
\text { et al., } 2011 \text { [22] }\end{array}$ \\
\hline 8 & $\begin{array}{c}\text { Aeromonas } \\
\text { hydrophila } \text { strain } \\
\text { RB5-M1 }\end{array}$ & Proteobacteria & $\begin{array}{c}\text { Gram-negative, } \\
\text { facultative } \\
\text { anaerobic }\end{array}$ & $\begin{array}{c}\text { Mild diarrhea, } \\
\text { life-threatening } \\
\text { necrotizing fasciitis, } \\
\text { septicemia, meningitis, } \\
\text { cholera-like illness, and } \\
\text { hemolytic-uremic } \\
\text { syndrome }\end{array}$ & $\begin{array}{l}\text { Grim CJ et al., } \\
\quad 2013[13]\end{array}$ \\
\hline 9 & $\begin{array}{c}\text { Leclercia } \\
\text { adecarboxylata } \\
\text { strain HPC21 }\end{array}$ & Proteobacteria & $\begin{array}{l}\text { Gram-negative, } \\
\text { aerobic }\end{array}$ & Fever and leukocytosis & $\begin{array}{c}\text { Zelalem } \\
\text { Temesgen et al., } \\
1997[14]\end{array}$ \\
\hline 10 & $\begin{array}{c}\text { Streptomyces sp. } \\
\text { MJM3179 }\end{array}$ & Actinobacteria & $\begin{array}{c}\text { Gram-positive, } \\
\text { aerobic }\end{array}$ & Hypersensitivity & $\begin{array}{c}\text { Monk et al., } 2007 \\
{[17]}\end{array}$ \\
\hline 11 & $\begin{array}{l}\text { Sphingomonas sp. } \\
\text { M16 }\end{array}$ & Proteobacteria & $\begin{array}{l}\text { Gram-negative, } \\
\text { aerobic }\end{array}$ & Infectious disease & $\begin{array}{l}\text { David C White } \\
\text { et al., } 1996 \text { [23] }\end{array}$ \\
\hline
\end{tabular}

\section{Discussion}

Our results indicate that schmutzdecke developed using water sourced from the Hyung-San River contains diverse and relatively high portions of opportunistic pathogens $(55 \%$ of all $\mathrm{HB}$ isolates were identified as opportunistic pathogens). Moreover, the results demonstrate a tendency toward an increased proportion of opportunistic pathogens in the schmutzdecke compared to its water source, suggesting that pathogens in the water source are trapped and attached to the sticky layer of the schmutzdecke and accumulated on the surface of the sand while water flows through the filter [9] 
(\% strain of the opportunistic pathogen increases from $29 \%$ in water sources to $55 \%$ in schmutzdecke). Our result is supported by the World Health Organization (WHO) report, which indicates that the microorganisms contained in water source attach to the surface of fine sand (Figure 1) and gradually accumulate to become part of the schmutzdecke [9]. However, in contrast with the WHO report, our study focused on pathogens more than on ordinary microorganisms. Concerning the underlying mechanism of schmutzdecke formation, as a whole, our study implies that the schmutzdecke developed by any water source containing pathogens could also contain opportunistic pathogens, as observed in our results; in other words, schmutzdecke acts as a trap for pathogens in the water source.

Moreover, diversity in the genus, phylum, and strains of opportunistic pathogens was increased in the schmutzdecke compared to the water sources. In the water source, six different genera were observed, while 12 different genera were observed in the schmutzdecke. Novosphingobium, Aeromonas, and Microbacterium were commonly found in both sample $\mathrm{H}$ and sample HB; however, Sphingomonas, Bradyrhizobium, Klebsiella, Enterobacter, Pantoea, Cloacibacterium, Streptomyces, Arthrobacter, and Brevibacillus were newly observed in schmutzdecke-originated samples (HB). Moreover, only two phyla (Proteobacteria and Actinobacteria) were observed in the water source, while four phyla (Proteobacteria, Actinobacteria, Firmicutes, and Bacteroidetes) were observed in the schmutzdecke. In the water source, four opportunistic pathogen strains (Raoultella ornithinolytica, Aeromonas caviae, Aeromonas hydrophila, and Leclercia adecarboxylata) were observed, whereas seven opportunistic pathogen strains (Klebsiella oxytoca, Enterobacter aerogenes, Pantoea agglomerans, Enterobacter cancerogenus, Novosphingobium aromaticivorans, Aeromonas hydrophila, and Streptomyces sp.) were observed in the schmutzdecke, indicating increased microbiological diversity in the schmutzdecke compared to the water source.

Aeromonas hydrophila, an opportunistic pathogen, was isolated from both schmutzdecke and raw water; on the other hand, there were strains that were isolated from either. Identified microorganisms in the schmutzdecke and raw water can differ because microorganisms from other sources besides raw water can also participate in the schmutzdecke. Microorganisms from other sources such as sand participate in the schmutzdecke, possibly inducing competition and microbial composition changes in the schmutzdecke.

Gomez-Villalba et al. applied a culture-independent method (temperature-gradient gel electrophoresis - TGGE) to analyze biofilm in a pilot-scale submerged biofilter and found that most of the species belonged to the Proteobacteria phylum [26]. This is consistent with our result that most of the species found in the schmutzdecke (biofilm) were Proteobacteria, perhaps indicating that Proteobacteria survive well in biofilm and water-associated conditions. Furthermore, Feng et al. reported that they detected the opportunistic pathogen Sphingomonas in the microbial community in the sand body portion of biosand filters and in the granular activated carbon-sand dual media filter portion by using $16 \mathrm{~S}$ rRNA gene clone library analysis [27,28]. Although the work of Feng et al. was more focused on simple microbial communities at $0.2 \mathrm{~m}$ depth in the sand body of filters and our study mainly focused on the schmutzdecke (biofilm) in the upper portion of the fine sand, the work of Feng et al. is consistent with our results relating to Sphingomonas detection.

Our results demonstrate that the schmutzdecke developed with water sourced from the Hyung-San River contains diverse fecal pollution indicators, such as Klebsiella oxytoca, Pantoea agglomerans, and Enterobacter aerogenes, which are reported to cause various infections threatening public health. 
Because many of the water sources in developing countries or rural areas are more or less contaminated with excreta or endemic pathogens [1], it can be predicted that BSFs applied in those areas will develop schmutzdecke containing opportunistic pathogens. Opportunistic pathogens and associated diseases will vary depending on the water sources, but it is clear that careless treatment of schmutzdecke containing opportunistic pathogens will be a potential hazard to public health.

The schmutzdecke plays a key role in the biosand filter due to its biological purifying function. Since few pathogens were detected in the treated water according to the previous studies, people implicitly assume that neither will there be barely any pathogens in the schmutzdecke layer. It is more like common sense to assume no pathogen survives in the schmutzdecke due to its purifying effects and this can eventually lead to the careless treatment of the schmutzdecke waste. However, looking from a different angle, our study tried to estimate whether there really is no pathogenic microorganisms in the schmutzdecke and we found that there are diverse opportunistic pathogens in the schmutzdecke. Nonetheless, our study is still limited to explain what the influence of purifying mechanisms was on the pathogenic microorganisms that were identified. Therefore, the further study dealing with the underlying mechanism of the phenomenon is expected to be followed for better understanding of the schmutzdecke.

Because schmutzdecke clogs and prevents water flow through the filter as it develops, it should be cleaned or discarded on a regular basis to maintain the BSF [10]. Although schmutzdecke contains diverse opportunistic pathogens that have potential for infection/disease outbreak, there are no solid guidelines for the after-treatment of schmutzdecke. Due to their characterization as appropriate technology, BSFs are mainly managed by rural or native people after installation. If the natives do not receive any cautionary or guiding information about the after-treatment of schmutzdecke, it is probable that they will dump or pour schmutzdecke deposits into the water source with little awareness when recharging BSFs. Disposal of the schmutzdecke deposit in the water source or anywhere that can flow to the water source should be restricted. This is because schmutzdecke (biofilm) is an accumulated and condensed form of microorganisms, including opportunistic pathogens; additionally, biofilm is a protected form that survives better and longer in aqueous conditions [29,30]. Consequently, the negative impacts of pathogens are potentially amplified and prolonged, which, in extreme cases, could result in epidemic outbreaks. Even a small quantity of pathogens in a water source that previously caused no conspicuous harm to people could turn into a significant hazard as the microbes form schmutzdecke (biofilm) because biofilm has a resilient nature that leads to persistent infections in humans [29].

Our main purpose of the study is to spot the microbial status of schmutzdecke at the point when the schmutzdecke waste should be treated, and thus we selected single sampling event point when the schmutzdecke in our experimental filter is saturated. In terms of the schmutzdecke waste, the periodic point when the schmutzdecke waste should be discarded varies depending on the turbidity and the flow rate of water. However, generally, replacing of the schmutzdecke is required when it is saturated, and thus the flow rate drops to a level that is inadequate for the household use. Even though we tried to spot microbial status of the schmutzdecke when it is treated, our study is still limited to single sampling event. Therefore, the further study dealing with samples from diverse periodic points should be followed to trace microbial change of the schmutzdecke in the long term performance of the BSF. 
As mentioned in the introduction, 12,346 institutions (this value includes only the official count) are supplying BSFs to more than 37 developing countries [5]. Although BSFs are widely applied in the field, there has been no study of the potential risks of schmutzdecke waste so far. Although our study does not include a variety of water sources, it still has significance in suggesting the potential risk of schmutzdecke and the necessity of creating guidelines or regulations for the after-treatment of schmutzdecke deposits. A cautious approach and careful attention are needed in treating schmutzdecke deposits. The results of the present study should be used as scientific background to revise and add guidelines for the after-treatment of schmutzdecke to BSF manuals. Once the manuals are revised and proper hygiene education is provided to local habitants by the BSF-supplying institutions, potential infections or epidemics caused by the careless treatment of schmutzdecke can be expected to be prevented.

\section{Conclusions}

We have evaluated the potential risk associated with schmutzdecke in biosand filters and its potential clinical impacts on human health in relation to diseases and infections. Opportunistic pathogens were identified by $16 \mathrm{~S}$ rRNA-based phylogenetic analysis, and the results suggest that schmutzdecke, indeed, contains diverse opportunistic pathogens that are reported to be capable of causing infections in human. Rather than covering a variety of water sources, our study dealt the schmutzdecke developed using a specific water source to evaluate the potential risk of schmutzdecke deposits and the potential clinical impact in detail. However, further study of schmutzdecke developed using various water sources should be conducted to confirm the potential danger suggested by our study. Furthermore, although we referred to previously reported information to suggest the pathogenic effects of the isolates, this report does not necessarily confirm an actual pathogenic effect. Thus, readers should interpret our results as suggestive of the "potential" risk of schmutzdecke and its waste.

\section{Acknowledgments}

The authors would like to thank Choi Jae Ho, Kim Gi Seok, Kim Young Rock, Yoon Woong Hee and Jin Young for their support and encouragement. Also, thanks to Kang Min for financial management and STAR program of Handong Global University CCER for their financial support.

\section{Conflicts of Interest}

The authors declare no conflict of interest.

\section{Author Contributions}

Min Seo Kim and Hyun Gyu Hwang designed research; Min Seo Kim, Hyun Gyu Hwang, and Soo Min Shin conducted research; Min Seo Kim, Hyun Gyu Hwang, and Cher Won Hwang analyzed data; Min Seo Kim and Hyun Gyu Hwang wrote the paper; Min Seo Kim, Hyun Gyu Hwang, Soo Min Shin and Cher Won Hwang revised the article for intellectual content; Cher Won Hwang had primary responsibility for the final content. All authors read and approved the final manuscript. 


\section{References}

1. Ashobolt, N.J. Microbial contamination of drinking water and disease outcomes in developing regions. Toxicology 2004, 198, 229-238.

2. Sianipar, C.P.M.; Yudoko, G.; Dowaki, K.; Adhiutama, A. Design methodology for appropriate technology: Engineering as if people mattered. Sustainability 2013, 5, 3382-3425.

3. Clifford, M.J. Appropriate technology: The poetry of science. Sci. Christ. Belief. 2005, 17, 71-82.

4. Centre for Affordable Water and Sanitation Technology (CAWST). 2012 Annual Report; CAWST: Alberta, AB, Canada, 2012; pp. 1-36.

5. Biosand Filter Info. Projects. Available online: http://www.biosandfilters.info/projects (accessed on 26 December 2013).

6. Stauber, C.E.; Elliott, M.A.; Ortiz, G.M.; DiGiano, F.A.; Sobsey, M.D. Charactersation of the biosand filter for $E$. coli reductions from housegold drinking water under controlled laboratory and filed use conditions. Water Sci. Technol. 2006, 54, 1-7.

7. Palmateer, G.; Manz, D.; Jurkovic, A.; Mclnnis, R.; Unger, S.; Kwan, K.K.; Dutka, B.J. Toxicant and parasite challenge of manz intermittent slow sand filter. Environ. Toxicol. 1999, 14, 217-225.

8. Barnes, D.; Collin, C.; Ziff, S. The Biosand. Filter, Shiphon. Filter, and Rainwater Harvesting: Strategic Recommendation for New Water Treatment Technologies and Safe Water Storage to Pure Home Water; Massachusetts Institute of Technology: New York, NY, USA, 2009; pp. 1-61.

9. World Health Organization (WHO). Slow Sand Filtration; WHO: Geneva, Switzerland, 1974; pp. 1-120.

10. Centre for Affordable Water and Sanitation Technology (CAWST). Biosand Filter Manual; CAWST: Alberta, AB, Canada, 2009; pp.1-129.

11. Centre for Affordable Water and Sanitation Technology (CAWST). Household Water Treatment and Safe Storage Fact Sheet: Biosand Filter; CAWST: Alberta, AB, Canada, 2009; pp.1-5.

12. Basic Local Alignment Search Tool. Available online: http://blast.ncbi.nlm.nih.gov (accessed on 13 November 2013).

13. Tamura, K.; Stecher, G.; Peterson, D.; Filipski, A.; Kumar, S. MEGA6: Molecular Evolutionary Genetics Analysis version 6.0. Mol. Biol. Evol. 2013, 30, 2725-2729.

14. Gabriel, B. Microbial Indicators of Fecal Contamination: Application to Microbial Source Taking; University of Florida: Gainesville, FL, USA, 2005; pp. 1-71.

15. Grim, C.J.; Kozlova, E.V.; Sha, J.; Fitts, E.C.; van Lier, C.J.; Kirtley, M.L.; Joseph, S.J.; Read, T.D.; Burd, E.M.; Tall, B.D.; et al. Characterization of Aeromonas hydrophila wound pathotypes by comparative genomic and functional analyses of virulence genes. MBio 2013, 4, 1-13.

16. Temesgen, Z.; Douglas, R.T.; Franklin, R.C. Leclercia adecarboxylata infections: Case report and review. Clin. Infect. Dis. 1997, 25, 79-81.

17. Morais, V.P.; Daporta, M.T.; Bao, A.F.; Campello, M.G. Enteric fever-like syndrome caused by Raoultella ornithinolytica (Klebsiella ornithinolytica). J. Clin. Microbiol. 2009, 47, 868-869.

18. Meiyanti; Salim, O.C.; Surjawidjaja, J.E.; Lesmana, M. Isolation and antibiotic sensitivity of Aeromonas from children with diarrhea. Univ. Med. 2010, 29, 14-20. 
19. Kapadia, M.; Rolston, K.V.; Han, X.Y. Invasive Streptomyces infections: Six cases and literature review. Am. J. Clin. Pathol. 2007, 127, 619-624.

20. Menard, A.; Harambat, J.; Pereyre, S.; Pontailler, J.R.; Megraud, F.; Richer, O. First report of septic arthritis caused by Klebsiela oxytoca. J. Clin. Microbiol. 2010, 48, 3021-3023.

21. Galani, I.; Souli, M.; Koratzanis, E.; Koratzanis, G.; Chryssouli, Z.; Glamerellou, H. Emerging bacterial pathogens: Escherichia coli, Enterobacter aerogenes and Proteus mirabilis clinical isolates harbouring the same transferable plasmid coding for metallo-beta-lactamase VIM-1 in Greece. J. Antimicrob. Chemoth. 2007, 59, 578-579.

22. Cruz, A.T.; Cazacu, A.C.; Allen, C.H. Pantoea agglomerans, a plant pathogen causing human disease. J. Clin. Microbiol. 2007, 45, 1989-1992.

23. Stock, I.; Wiedemann, B. Natural antibiotic susceptibility of Enterobacter amnigenus, Enterobacter cancerogenus, Enterobacter gergoviae and Enterobacter sakazakii strains. Clin. Microbiol. Infect. 2002, 8, 564-578.

24. Mohammed, J.P.; Fusakio, M.E.; Rainbow, D.B.; Moule, C.; Fraser, H.I.; Clark, J.; Todd, J.A.; Peterson, L.B.; Savage, P.B.; Wills-Karp, M.; et al. Identification of Cd101 as a susceptibility gene for Novosphingobium aromaticivorans-induced liver autoimmunity. J. Immunol. 2011, 187, 337-349.

25. White, D.C.; Sutton, S.D.; Ringelberg, D.B. The genus Sphingomonas: Physiology and ecology. Environ. Biotech. 1996, 7, 301-306.

26. Gomez, V.B.; Calvo, C.; Vilchez, R.; Gonazlez, L.J.; Rodelas, B. TGGE analysis of the diversity of ammonia-oxidizing and denitrifying bacteria in submerged filter biofilms for the treatment of urban wastewater. Appl. Microbiol. Biot. 2006, 72, 393-400.

27. Feng, S.; Chen, C.; Wang, Q.; Yang, Z.; Zhang, X.; Xie, S. Microbial community in a full-scale drinking water biosand filter. J. Environ. Biol. 2013, 34, 321-324.

28. Feng, S.; Chen, C.; Wang, Q.F.; Zhang, X.J.; Yang, Z.Y.; Xie, S.G. Characterization of microbial communities in a granular activated carbon-sand dual media filter for drinking water treatment. Int. J. Environ. Sci. Te. 2013, 10, 917-922.

29. Kolari, M. Attachment Mechanisms and Properties of Bacterial Biofilms on Non-Living Surfaces; University of Helsinki: Helsinki, Finland, 2003; pp. 1-79.

30. Szewzyk, U.; Szewyk, R.; Manz, W.; Schleifer, K.H. Microbiological safety of drinking water. Annu. Rev. Microbiol. 2000, 54, 81-127.

(C) 2014 by the authors; licensee MDPI, Basel, Switzerland. This article is an open access article distributed under the terms and conditions of the Creative Commons Attribution license (http://creativecommons.org/licenses/by/3.0/). 